\title{
Managemen Konflik Mahasiswa: Destruktifkah?
}

\author{
Fathul Lubabin Nuqul \\ Fakultas Psikologi \\ Universitas Islam Negeri Maulana Malik Ibrahim Malang \\ lubabin_nuqul@uin-malang.ac.id \\ Ardana Reswari Miranda Ningrum \\ Fakultas Psikologi \\ Universitas Islam Negeri Maulana Malik Ibrahim Malang \\ ardana_ningrum@yahoo.com \\ Mochammad Sulaiman Zuhdi \\ Fakultas Psikologi \\ Universitas Islam Negeri Maulana Malik Ibrahim Malang \\ mochamadzada@gmail.com
}

\begin{abstract}
Abstrak
Konflik kondisi yang ditandai dengan gesekan antar pihak. Konflik tidak selalu menghasilkan akibat yang negatif. Kondisi positif juga kerap muncul mengikuti konflik yang terjadi. Ketepatan menyikapi atau memanage menjadi kunci bentuk akibat konflik. Johnson \& Johnson (2014) membagi managemen konflik ke dalam dua kategori besar yaitu destruktif maupun konstruktif. Mahasiswa merupakan insan akademik yang diharapkan mampu menyikapi segala kondisi dengan baik. Hal ini menjadi harapan yang wajar karena mahasiswa diharapkan menjadi pemimpin dimasa yang akan datang. Penelitian ini bertujuuan untuk melihat pola managemen konflik yang pilih oleh mahasiswa ditinjau dari lama dia studi di kampus. Penelitian ini melibatkan 164 mahasiswa. Pengukuran menggunakan conflict management style scale. Hasilnya menunjukkan bahwa umumnya mahasiwa menunjukkan gaya managemen konflik yang konstruktif, namun ada perbedaan pada tahun studi. Mahasiswa baru cenderung lebih destruktif dibanding dengan mahasiswa yang lama
\end{abstract}

Kata Kunci: konflik, managemen konflik, mahasiswa

\section{Pendahuluan}

Dalam kajian psikologi dijelaskan bahwa manusia mempunyai kebutuhan untuk bersosialisasi, dihargai oleh orang lain (Maslow, 1943). Ini menunjukkan bahwa manusia adalah mahluk sosial yang tak bisa dipisahkan keberadaannya dari orang lain. Fitrah manusia ini bukan tanpa resiko, banyak terjadi problem di 
sebuah kelompok mulai pembentukanya, perumusan norma, konflik dan dinamika pengambilan keputusan yang rumit dalam kelompok (Forsyith, 2010).

Konflik menjadi kajian yang tetap menarik untuk diungkap. Konflik dianggap sebagai kondisi yang mengakibatkan memburuknya relasi sosial bahkan tatanan sosial kemasyarakatan. Meskipun tidak selalu berefek negatif, konflik dirasa sangat mengerikan ketika harus melibatkan dua kekuatan atau dua pihak yang harus berhadapan (Alfinuha, Rohyatin \& Nuqul. 2017).

Konflik dapat terjadi karena adanya kecenderungan dari salah satu pihak yang berseteru untuk mengklaim dirinya paling benar maupun mengedepankan kepentingannya (Kolb, 1992). Konflik juga bisa muncul karena berkurangnya sumberdaya materi, misalnya Social Conflict Afrika Database (SCAD) mengemukakan bahwa minimnya curah hujan yang berhubungan dengan semua jenis konflik dan kekerasan politik (Hendrix \& Salehyan, 2012).

Konflik dilatarbelakangi oleh perbedaan ciri-ciri yang dibawa individu dalam sebuah interaksi orang lain. perbedaan-perbedaan tersebut diantaranya adalah menyangkut ciri fisik, kepandaian, pengetahuan, adat istiadat, keyakinan, dan lain sebagainya (Rachmadani, 2013). Dengan dibawa sertanya ciri-ciri individual dalam interaksi sosial, konflik merupakan situasi yang wajar dalam setiap masyarakat dan tidak satu masyarakat pun yang tidak pernah mengalami konflik antar anggotanya atau dengan kelompok masyarakat lainnya, konflik hanya akan hilang bersamaan dengan hilangnya masyarakat itu sendiri.

Konflik terjadi jika terdapat perbedaan dalam ketersediaan sumberdaya, perbedaan tujuan yang ingin dicapai atau cara pencapaian tujuan. Juga bisa terjadi karena perasaan bahwa pencapaian tujuan diganggu (diintervensi) oleh pihak lain. Biasanya konflik melibatkan dua pihak atau lebih (interpersonal \& intergroup), namun bisa juga satu pihak (intrapersonal, intragroup) dengan kepentingan berbeda-beda (Johnson \& Johnson, 1999: Forsyith, D. 2010). .

Masyarakat Indonesia yang terdiri dari berbagai suku, ras, dan agama rentan mengalami konflik. Aisyah, (2014) mengemukakan bahwa Ketidakmampuan untuk menginterpretasi isi dari ayat-ayat dari kitab suci, mengakibatkan hilangnya arah bahkan ketidakpastian yang kemudian 
mengakibatkan keputus asaan, menjadi salah satu hal pemicu konflik. Dari uraian ini konflik bisa dipengauhi oleh kondisi internal, relasi kelompok atau juga kondisi yang serba kekurangan.

Dampak tersebut berupa dampak fisik, psikologis, sosial, ekonomi, dan budaya. Konflik akan membawa perubahan masyarakat yang mengakibatkan perbedaan dari kehidupan sebelumnya. Apabila dampak yang timbul itu adalah positif maka akan adanya peningkatan hubungan baik antar warga, namun apabila dampak yang timbul itu negatif, justru akan menjadikan kehidupan yang sudah ada akan menjadi lebih buruk. Dampak negatif ini juga bisa mejadikan konflik yang telah terjadi tidak terselesaikan, melainkan akan berkembang semakin besar dan berbahaya bagi kehidupan dimasa yang akan datang. (Kurniawan \& Syani, 2012).

Berbagai macam konflik antar kelompok di Indonesia yang tercatat cukup menguatkan rasa takut pada masyarakat. Data menunjukkan ada 18.910 orang Indonesia mati akibat konflik baik yang terjadi di Aceh, Poso, Sampit, Papua dan Maluku sejak Oktober 1998-September 2001 (Malik, 2003).

Konflik tidak terhindarkan jika pihak-pihak yang bertentangan tidak memiliki pemahaman yang terhadap satu sama lain dan tujuan serta kebutuhan mereka tidak dapat lagi sejalan (Forsyith, 2010). Perbedaan pendapat yang terjadi di antara keduanya pada dasarnya adalah hal yang alami, namun jika tidak terkendali akan menjadi pemicu timbulnya kekerasan yang merusak kedua belah pihak bahkan lingkungan sekitarnya.

Konflik merupakan fakta kehidupan yang dapat memunculkan permasalahan-permasalahan berat saat kekerasan muncul dalam konflik tersebut (Malik 2003). Dalam menghadapi konflik terdapat dua pola yang berbeda yaitu kelompok yang meyakini bahwa kekerasan merupakan penyelesaian konflik yang baik. Di sisi lain terdapat juga kelompok yang anti kekerasan. Kelompok yang pro kekerasan cenderung menggunakan daya paksa untuk mencapai kehendaknya agar dituruti orang lain. Adapun kelompok anti kekerasan cenderung meyakini bahwa kekerasan tidak akan mampu mencapai kebaikan yang diharapkan, sehingga penggunaan kekerasan dirasa tidak bermanfaat dan tidak adil (Forsyith, 2010), 
maka gaya managemen konflik menjadi penting untuk dibahas pada level mahasiswa.

\section{Managemen Konflik}

Konflik tidak bisa disebut negatif atau positif dengan sendirinya, tetapi penilaian positif atau negatif dari konflik tergantung dari pilihan cara, mekanisme yang ditempuh dalam penyelesaian konflik, dan makna yang bisa dipelajari dari terjadinya konflik.Sikap dan respon seseorang menghadapi konflik disebut dengan gaya manajemen konflik. Gaya manajemen konflik terbagi menjadi enam, (Johnson \& Johnson, 2014) yaitu: menghindar, menolak, konfrontasi, kompromi, argumentatif, pemecahan masalah. Pertama, Menghindar, seseorang dengan gaya konflik menghindar,berkecenderungan menghindar dan menjauhi konflik. Karena individu cenderung merasahopeless pada resolusi konflik, cara "lari" dari konflik baik secara fisik maupun secara psikologis lebih dipilih individu dibanding menghadapi konflik tersebut. Kedua,konfrontasi, mempunyai kecenderungan menunjukkan kekuatan pada lawannya dengan memaksa lawannya untuk menerima solusi konflik dari dirinya. Bagi mereka, tujuan pribadi merupakah hal yg lebih penting dibanding dengan berinteraksi dengan orang lain. Individu berusaha merealisasikan tujuannya dengan segala cara dan tidak mempedulihan oranglain.Ketiga, kompromis, individu dengan kecenderungan tipe ini berinteraksi dengan orang lain lebih penting dari tujuan pribadinya. Mereka lebih menginginkan penerimaan dari orang lain. Baginya konflik akan menjauhkan dari keharmonisan. Keempat,argumentatif, memberikan penjelasan pada orang lain merupakan hal yang sangat penting bagi seseorang yang mempunyai gaya konflik ini. Tujuan penjelasan yang diberikan adalah ingin lawan konfliknya memahami dasar-dasar keinginannya secara persuasif. Kelima, konfirmatif. Berfikir kritis merupakan elemen yang penting bagi seseorang yang cenderung berkaya konfirmatif. Skeptisme dan terbuka terhadap saran menjadi kunci dalam penyelesaian konflik ini. Keenam adalah gaya konflik pemecah masalah: seseorang menempatkan tujuan pribadi dan interaksi dengan pada posisi yang tinggi. Konflik merupakan kondisi yang harus dicari solusinya untuk mencapai tujuan dan keharmonisan dengan orang lain. Individumenganggap bahwa konflik 
merupakan kondisi yang bisa meningkatkan interaksi dengan orang lain dengan cara menurunkan tention antara kedua belah pihak. Individu merasa puas jika konfik benar-benar terselesaikan

Dari keenam gaya konflik yang ada dapat digolongkan menjadi gaya konflik yang konstruktif dan destruktif. Gaya konflik yang konstruktif merupakan gaya konflik yang mempunyai kecenderungan positif, membangun serta berorientasi damai dalam menyelesaikan konflik. Di sisi lain destruktif mempunyai kecenderungan menghadapi konflik dengan cara yang tidak berpihak penyelesaian secara positif serta cenderung menganggap konflik adalah masalah yang negatif. Gaya konflik destruktif, meliputi gaya konflik menghindar, menolak dan konfrontasi dan gaya konflik yang konstruktif meliputi pemecah masalah, konfirmasi dan argumentatif (lih. Mardianto, Koentjoro, \& Purnamaningsih, 2000)

Mahasiswa merupakan kaum yang terdidik. Setelah menempuh pendidikan dasar dan pendidikan tingkat lanjut, mahaiswa digembleng di kampus dengan kehidupan yang lebih mengedepankan kapasistas intelektual dan kematangan emosi. Mahasiswa merupakan insan yang dianggap mempunyai kematangan intelektual, diharapkan mampu menjadi agen perubahan dari kondisi yang penuh konflik ke kondisi yang penuh kedamaian. Dalam tinjauan perkembangan manusia, mahasiswa berada pada fase antara remaja akhir sampai dewasa awal. Pada fase perkembangan ini mahasiswa secara kognisi sudah mampu berfikir dan mengambil keputusan dengan baik, berpikir kritis-analitis, rasional dan inovatif (Santrock, 2012) Dengan kapasitas perkembangan tersebut serta pengaruh lingkungan pendidikan kampus, mahasiswa diharapkan mampu berperan sebagai agen perubahan dalam sosial dan calon pemimpin masa depan. Meskipun demikian mahasiswa tidak lepas dari kondisi yang penuh konflik, baik dalam organisasi maupun dalam kehidupan sosial lainnya (Mardianto, et al, 2000). Oleh karena itu kemampuan manajemen konflik merupakan kemampuan yang penting untuk dimiliki.

Realitanya, peristiwa mahasiswa terjebak pada perseteruan yang melibatkan fisik beberapa kali muncul di pemberitaan. Misalnya beberapa kasus 
tawuran antar mahasiswa di Makasar (Rakyatku News, 2017), juga di perguruan tinggi di Riau (Republika, 2017) serta pengroyokan mahasiswa di ambon (Kompas 2017) yang dipicu oleh kesalah fahman dan permasalahan hedonistic. Permasalahan yang juga sering konflik kekuasaan menjelang atau bahkan pasca pemilihan presiden BEM di kampus. Konflik terjadi antar kelompok mahasiswa maupun antara mahasiswa dengan birokrasi kampus. Konflik semakin meruncing karena keterlibatan organisasi ekstra (Dzulkifli\& Harianto 2017). Rangkaian peristiwa ini akan menurunkan penghargaan pada mahasiswa sebagai agen perubahan. Aziz dan Mangestuti (2006) meramalkan bahwa perilaku agresi mahasiswa cenderung meningkat baik secara verbal memfirnah, memaki maupun fisik seperti tawuran dan lain-lainnya.

\section{The Gap of Knowledge}

Penelitian tentang konflik telah banyak dilakukan, namun belum banyak yang memfokuskan tentang reaksi individu terhadap konflik secara psikologis. Penelitian tentang konflik banyak berfokus pada penelitian antar kelompok (Dhami \& Olsson, 2008; Kurniawan \& Syani, 2012), maupun konflik pada tataran individu (Hanselmann, \&Tanner, 2008; Robinson, Wilkowski, \& Meier, 2008)). Reaksi individu pada sesuatu tidak lepas dari budaya dan latar belakang yang ada (Ember, \& Ember, 2000) begitu juga dengan konflik. Belum banyak penelitian tentang managemen gaya konflik. penelitian tentang gaya managemen konflik yang ada diantaranya:Gayle dan Nugraheni (2012) pada mahasiswa yang berpacaran, juga pada anak di lapas (Priliantini, 2008).

Penelitian gaya managemen konflik pada mahasiswa masih cukup relevan dilakukan mengingat pola perubahan kehidupan kampus yang mengikuti perubahan zaman berpengaruh juga pada perubahan perilaku. Penelitian ini mengambil setting di Indonesia yang mempunyai budaya kolektifvis sehingga berbeda dengan penelitian pada masyarakat yang berbudaya individualis. Penelitian ini bertujuan untuk mengetahui kecenderungan gaya konflik pada mahasiswa. Pemilihan mahasiswa sebagai subjek dalam peneliian ini merupakan pilihan yang tepat. Untuk itu selain ingin mengetahui gaya konflik mahasiswa 
secara keseluruhan. Penelitian ini juga bertujuan melihat pengaruh lama studi di kampus dengan gaya konflik yang digunakan.

\section{Metode}

Subyek pada penelitian ini adalah mahasiswa fakultas psikologi yang keseluruhan berjumlah 164 orang mahasiswa (119 orang perempuan dan 45 orang laki-laki). 87 orang tercatat sebagai mahasiswa tahun pertama, 39 orang mahaiswa tahun kedua dan 39 mahasiswa tahun ke tiga. Subyek di libatkan dengan menggunakan random sampling

Instrument pengukuran dalam penelitian ini adalah gaya managemen konflik yang diadaptasi dari The Thomas-Kilmann Conflict Mode Instrument. Intrumen managemen konflik dari Thomas-Kilmann mempunyai 5 bentuk managemen konflik (konfrontatif, menghindar, argumentatif, konfirmasi dan problem solving). Johnson \& Johnson (2010) mengembangkan menjadi 6 bentuk dengan menambahan gaya konflik menolak.

Contoh item pada masing-masing managemen konflik. konfrontatif, "ketika saya tidak setuju dengan anggota kelompok yang lain, saya menuntut meraka untuk merubah pendapatnya agar sesuai dengan pendapat saya”; menolak, "jika seseorang tidak setuju dengan pendapat saya, saya merasa terluka dan ditolak"; menghindar: "saya mencoba menghindari perdebatan"; argumentatif: "saat orang lain tidak setuju dengan saya, maka saya akan menjelaskannya dari berbagai sudut pandang”; konfirmasi "ketika saya tidak setuju dengan orang lain, saya berusaha mengungkapkan dengan sopan"; problem solving: "saat orang lain tidak setuju dengan saya, saya menganggap bahwa kondisi ini adalah kesempatan untuk belajar bernegosiasi"

Dari penelitian ini diperoleh nilai alpha Cronbach pada sub skala gaya managemen konflik menghindar sebesar 0,539; gaya managemen konflik menang kalah sebesar: 0,710; gaya managemen konflik menolah sebesar 0,711 ; gaya managamen konflik konfirmatif: 0,441; gaya managemen konflik argumentatif sebesar 0,547; gaya managemen konflik problem solving sebesar 0,617. 


\section{Hasil dan Pembahasan}

\section{Gaya Konflik: Konstruktif vs Destruktif}

Untuk menjawab pertanyaan penelitian tentang kecenderungan gaya konflik dari mahasiswa maka dilakukan deskriptif. Dari tabel 1, menunjukkan bahwa secara umum mahasiswa fakultas psikologi, mempunyai kecenderungan managemen konflik yang konstruktif. Hal ini dapat dlihat dari rerata gaya menagemen konflik konstriktif lebih tinggi dibandingkan dengan gaya managemen konflik yang destruktif. Hal ini menunjukkan bahwa mahasiswa cenderung lebih bisa menyikapi dan menangani konflik yang dimilikinya secara baik dan membangun.

Tabel 1. Hasil Analisis deskriptif managemen konflik desktruktif dan managemen konflik konstruktif

\begin{tabular}{lcccc}
\hline Gaya Konflik & Minimum & Maximum & Rerata & Std. Deviasi \\
\hline Destruktif & 21 & 53 & 33.98 & 6.554 \\
Konstruktif & 39 & 71 & 55.18 & 5.985 \\
\hline
\end{tabular}

Untuk lebih terperinci berikut ini masing-masing gaya managemen konflik baik yang destruktif (menang-kalah, penolakan dan menghindar) maupun yang konstruktif (berargumen, konfirmasi, dan pencarian problem solving) sebagaimana table berikut:

Tabel 2. Hasil Analisis Deskriptif Pada Masing-Masing Dimensi Managemen Konflik Desktruktif Dan Managemen Konflik Konstruktif

\begin{tabular}{lrrrr}
\hline Dimensi & Minimum & Maximum & \multicolumn{1}{c}{ Rerata } & \multicolumn{1}{c}{ Std. Deviasi } \\
\hline Konfrontatif & 6 & 24 & 12.36 & 3.657 \\
Penolakan & 5 & 17 & 7.99 & 2.545 \\
Menghindar & 5 & 20 & 13.63 & 2.880 \\
Argumentatif & 12 & 23 & 17.20 & 1.993 \\
Konfirmasi & 10 & 25 & 18.57 & 2.545 \\
Pemecahan Masalah & 12 & 25 & 19.41 & 2.810 \\
\hline
\end{tabular}

Dari tabel 2 menunjukkan bahwa semua dimensi dari manajemen konflik konstruktif (mencari solusi, argumentasi dan mencari konfirmasi) merupakan gaya yang paling banyak dipilih dalam menghadapi konflik, sebaliknya 
mahasiswa kecenderungan untuk menolak atau pengabaian konflik merupakan hanya manajemen konflik yang cenderung tidak dipilih.

\section{Gaya Manajemen Konflik pada mahasiswa antar tahun}

Gaya konflik terdiri dari konstruktif dan destruktif. Untuk dekstruktif menunjukkan hasil ada pengaruh lama studi dengan gaya konflik mahasiswa. ( $\mathrm{F}=$ $7.705 ; \mathrm{p}<0.01)$

Tabel. 3

Hasil Analisis Post Hoc Gaya Managemen Konflik Dekstruktif Antar Tahun Studi

\begin{tabular}{llrlll}
\hline & & Rerata & 1 & 2 & 3 \\
\hline 1 & Mahasiswa tahun 1 & 37.44 & - & & \\
2 & Mahasiswa tahun 2 & 32.62 & $4.821^{*}$ & - & \\
3 & Mahasiswa tahun 3 & 33.07 & $4.368^{*}$ & 0.452 & - \\
\hline '* $\mathrm{p}>0,01=$ signifikan & & & &
\end{tabular}

Dengan kata lain apakah mahasiswa yang lebih lama dalam menjalani kehidupan belajar dikampus lebih mempunyai gaya managemen konflik yang konstruktif atau sebaliknya. Dari hasil analisis deskripsi, pada managemen konflik dekstruktif menunjukkan mahasiswa psikologi yang masih pada tahun pertama mempunyai kecenderungan managemen yang lebih dekstruktif hal ini bisa tergambar tingginya rerata yang paling tinggi dibanding dengan managemen mahasiswa yang sudah kuliah memasuki tahun ke 3 dan tahun ke 2. Perbedaaan ini juga ditunjukkan dengan analisis post hoc bahwa rerata manajemen dekstruktif mahasiswa tahun pertama leih tinggi secara signifikan dibanding dengan mahasiswa tahun ke dua dan ketiga. Mahasiswa di tahun kedua dan tahun ketiga tidak mempunyai perbedaan kecenderungan managemen konflik destruktif.Untuk gaya manajemen konflik konstruktif menunjukkan tidak ada perbedaan antara tahun studi $(\mathrm{F}=2.292 ; \mathrm{p}>0,05)$, artinya bahwa semua subyek cenderung mempunyai niatan yang baik ketika menghadapi konflik.

Tabel 4. Hasil Analisis Post Hoc Gaya Managemen Konflik Konstruktif Antar Tahun Studi

\begin{tabular}{llrlll}
\hline & Masa Studi & Rerata & 1 & 2 & 3 \\
\hline 1 & Mahasiswa tahun 1 & 55.81 & - & & \\
2 & Mahasiswa tahun 2 & 55.51 & 2.103 & - & \\
3 & Mahasiswa tahun 3 & 53.41 & $2.399^{*}$ & 0.296 & - \\
\hline$* \mathrm{p}>0,05=$ signifikan & & & &
\end{tabular}


Dari hasil analisis deskripsi, pada managemen konflik konstruktif mahasiswa psikologi yang masih pada tahun pertama mempunyai kecenderungan manajemen yang lebih dekstruktif hal ini bisa tergambar tingginya rerata yang paling rendah dibanding dengan manajemen mahasiswa yang sudah kuliah memasuki tahun ketiga dan tahun kedua, perbedaaan ini juga ditunjukkan dengan analisis post hoc bahwa rerata managemen konstruktif mahasiswa tahun pertama lebih rendah secara signifikan dibanding dengan mahasiswa tahun ke dua dan ketiga. Adapun untuk mahasiswa di tahun kedua dan tahun ketiga tidak mempunyai perbedaan kecenderungan managemen konflik konstruktif.

\section{Perbedaan Gaya Konflik}

Guna memperjelas pada masing-masing gaya managemen konflik maka berikut ini dilakukan uji analisis pada masing-masing gaya managemen konflik yang meliputi kalah menang, menghindar, menolak, konformasi, argumentasi dan mencari solusi.

\section{Gaya Konflik: Konfrontatif}

Dari hasil analisis menunjukkan bahwa ada pengaruh tahun studi dengan tingkat konfrontasi dalam konflik $(\mathrm{F}=5.079 ; \mathrm{p}<0,05)$. Adapun perbedaan antar tahun secara terperinci sebagai pada tabel 5 , menunjukkan bahwa mahasiswa para tahun pertama lebih cenderung mempunyai gaya konfrontatif dibanding dengan mahasiswa tahun ke dua dan ketiga.

Tabel 5. Analisis Post Hoc konfrontatif

\begin{tabular}{llrlll}
\hline & Masa Studi & Rerata & 1 & 2 & 3 \\
\hline 1 & Mahasiswa tahun 1 & 11.93 & - & & \\
2 & Mahasiswa tahun 2 & 11.74 & $2.205^{*}$ & - & \\
3 & Mahasiswa tahun 3 & 13.95 & $2.016^{*}$ & 0.189 & - \\
\hline ‘* $\mathrm{p}<0,01=$ signifikan & & &
\end{tabular}

\section{Gaya Konflik Penolakan}

Dari hasil analisis menunjukkan bahwa tidak ada pengaruh tahun studi dengan tingkat penolakan dalam konflik $(\mathrm{F}=2.086 ; \mathrm{p}>0.05)$. artinya tidak ada perbedaan antara mahasiswa pada tahun pertama, ke dua dan ketidak pada kecenderungan penolakan dalam konflik. 
Tabel 6. Analisis Post Hoc Penolakan

\begin{tabular}{llrlll}
\hline & Masa Studi & Rerata & 1 & 2 & 3 \\
\hline 1 & Mahasiswa tahun 1 & 8.72 & - & & \\
2 & Mahasiswa tahun 2 & 7.77 & $0.942^{*}$ & - & \\
3 & Mahasiswa tahun 3 & 7.78 & $0.943^{*}$ & $0.06^{*}$ & - \\
\hline ‘* $\mathrm{p}>0,5=$ tidak signifikan & & & &
\end{tabular}

\section{Gaya Konflik Menghindar}

Dari hasil analisis menunjukkan bahwa ada pengaruh tahun studi dengan tingkat kecenderungan menghindari konflik $(\mathrm{F}=4.258 ; \mathrm{p}<0,5)$. Secara terperinci sebagaimana dalam tabel 7 menunjukkan bahwa mahasiswa tahun pertama cenderung menghindari konflik dibanding mahasiswa yang telah belajar di tahun ke dua dan ketiga. Di sisi lain mahasiswa pada tahun ke dua dan ke tiga tidak memiliki perbedaan.

Tabel 7. Analisis Post Hoc kecenderungan menghindari konflik

\begin{tabular}{llrlll}
\hline & Masa Studi & Rerata & 1 & 2 & 3 \\
\hline 1 & Mahasiswa tahun 1 & 14.77 & - & & \\
2 & Mahasiswa tahun 2 & 13.10 & $-1.667^{*}$ & - & \\
3 & Mahasiswa tahun 3 & 13.36 & $-1.410^{*}$ & 0.257 & - \\
\hline '* $\mathrm{p}<0,01=$ signifikan & & & &
\end{tabular}

Hasil deskriptif dan post hoc menunjukkan bahwa manajemen konflik menang kalah pada mahasiswa angkatan pertama menunjukkan rerata yang paling tinggi, hal ini berbeda secara signifikan dengan dibanding dengan mahasiswa di tahun ke dua dan tahun ketiga. Artinya bahwa mahasiswa yang masih kuliah di tahun pertama cenderung lebih berorientasi pada menang kalah dibanding mahasiwa yang lebih lama hidup dikampus. Dari analisis juga tidak ditemukan perbedaan menegemen konflik menang kalah antara mahasiswa angkatan kedua dengan mahasiswa angkatan tahun ketiga

Selanjutnya hasil deskriptif dan post hoc juga menunjukkan bahwa manajemen konflik menghindar pada mahasiswa angkatan pertama menunjukkan rerata yang paling tinggi, hal ini berbeda secara signifikan dengan dibanding dengan mahasiswa di tahun ke dua dan tahun ketiga, artinya bahwa mahasiswa yang 
masih kuliah di tahun pertama cenderung lebih ingin menghindari konflik dibanding mahasiwa yang lebih lama hidup dikampus. Dari analisis tersebut juga tidak ditemukan perbedaan manajemen konflik menghindar antara mahasiswa angkatan kedua dengan mahasiswa angkatan tahun ketiga. Untuk manajemen konflik menghindar tidak ada perbedaan antara masing-masing kelompok mahasiswa.

\section{Managemen Konflik Konstruktif}

Dari hasil analisis varian menunjukkan bahwa gaya manajemen konflik konfirmasi $(\mathrm{F}=2.732 ; \mathrm{p}<0,05)$ dan gaya manajemen konflik argumentatif $(\mathrm{F}=$ 1.892; $\mathrm{p}<0,05)$ serta gaya manajemen konflik solutif $(\mathrm{F}=0.608 ; \mathrm{p}<0,05)$ tidak menunjukkan adanya perbedaan antar angkatan.

Selanjutnya hasil deskriptif dan post hoc tidak ditemukan perbedaan manajemen konflik berargumentasi dan pemecahan masalah antara mahasiswa angkatan kedua dengan mahasiswa angkatan tahun ketiga. Untuk manajemen konflik menghindar tidak ada perbedaan antara masing-masing kelompok mahasiswa.

\section{Diskusi}

Hasil menunjukkan bahwa secara umum mahasiswa sudah mampu melakukan manajemen konflik yang konstruktif. Hasil penelitian ini bertentangan dengan beberapa penelitian tentang reaksi konflik. Teori umumnya mengatakan bahwa ketika mengalami konflik, ekspresi yang muncul pada individu umumnya adalah emosi negatif seperti marah, benci, kesal, dan lain sebagainya. Emosi negatif ini diekspresikan melalui perilaku mengomel, memukul-mukul, berteriak, dan perilaku negatif yang lain (Falentina \& Yulianti, 2012). Hal ini menguatkan penelitian yang menjelaskan bahwa emosi umum individu ketika menghadapi konflik adalah emosi negatif (Baqi, 2015; Falentina \& Yulianti, 2012). Sehingga individu akan cenderung melakukan konfrontasi yang destruktif.

Salah satu alasan bahwa subjek mampu mempunyai ekspresi yang lebih konstruktif adalah bahwa mahasiswa diharapkan mampu mengekspresikan pemikiraan dan emosinya dengan baik dan lebih diterima oleh orang lain. Termasuk juga dalam mengekspresikan ketidak setujuan yang dirasakan. 
Sebagaimana fase perkembangan mahasiswa yang cenderung sudah matang dalam mengekspresikan emosi dan bersosialisasi (Santrock, 2012)

Dalam mengekpresikan ketidaksetujuannya,semakin tinggi usia seseorang akan makin mampu menyembunyikan emosi negatifnya. Dalam sebuah penelitian menunjukkan bahwa individu yang berada pada taraf perkembangan dewasa awal lebih mampu menyembunyikan kekecewaan akibat konflik yang dirasakan dibanding individu yang berada pada taraf remaja (Alfinuha, Rohyatin, \& Nuqul, 2017). Kemampuan dalam menyikapi konflik juga dipengaruhi oleh kapasitas pribadi seseorang, dalah satunya adalah kepasitas intelektual dan pengalaman (Forsyth, 2010). Kehidupan di kampus memberikan pengalaman pada mahasiswa menyikapi dan berekasi pada dunia ekternalnya, termasuk diantaranya sumber konflik.

Keyakinan ini juga dibuktikan bahwa pada mahasiswa yang menjadi tahun pertama masih cenderung mempunyai kecenderungan untuk melakukan manajemen konflik yang cenderung konfrontatif juga menolak adanya konflik. Penolakan terhadap konflik lazim ditemukan pada mahasiswa yang masih berada pada fase remaja yang masih ingin diterima oleh lingkungan. Pengalaman mahasiswa dalam kehidupan kampus seperti berorganisasi mempengaruhi kematangan dalam menghadapi konflik (Mardianto, et al, 2000)

Hasil juga menunjukkan bahwa mahasiwa yang masih kuliah di tahun pertama cenderung kurang cenderung mempunyai managemen konflik yang baik namun pada subyek pada tahun kedua cenderung mempunyai konflik yang lebih konstruktif. Kondisi ini tidak lepas dari anggapan bahwa pendidikan mampu merubah seseorang. Bahari (2010) mengatakan bahwa pendidikan itu adalah merupakan suatu proses (sejumlah proses secara bersama-sama) perkembangan, kemampuan, sikap dan bentuk tingkah laku lainnya yang berlaku dalam masyarakat tempat ia hidup. Masih menurut Bahari, (2010) bahwa pendidikan juga merupakan penciptaan lingkungan terpilih dan terkontrol (misalnya kampus) sehingga ia dapat mengembangkan diri pribadi secara optimum dan kompeten dalam kehidupan masyarakat (sosial). Selain itu juga kegiatan kependidikan tidak hanya berwujud pada pendidikan formal (sosial, agama, eksakta) namun banyak 
bentuknya yang setidaknya ada pendidik dan si terdidik sebgaimana yang diungkap oleh Hadari (2010) didalam kegiatan kependidikan sekurang-kurangnya dua orang atau lebih yang masing-masing menjalankan fungsi sebagai pendidik dan si terdidik atau anak yang harus dibantu, ditolong dan diarahkan agar mencapai kedewasaannya masing-masing sebagai tujuan.

Selain itu juga melihat dari lingkungan serta latar belakang responden, responden memiliki kesempatan yang sama dalam pengertian proses dan kegiatan belajar di lingkungannya sama-sama memperoleh pendidikan yang berhubungan dengan nilai-nilai toleransi dalam pembelajaran keagamaan di Ma'had UIN Malang. Hal ini merupakan salah satu faktor seseorang mendapatkan pendidikan yang terkait dengan toleransi serta berpengaruh pada perilaku hasil belajar seseorang.

Hasil penelitian ini menekankan sebuah kebutuhan untuk meningkatkan kapasitas soft skill mahasiswa dalam menghadapi perbedaan. Meskipun secara umum bahwa subyek yang sudah mempunyai gaya yang lebih positif, tetapi pada mahasiswa tahun-tahun pertama merupakan mahasiswa yang cukup rentang mengalami kegagalan dalam menghadapi konflik.

Dibandingkan dengan mahasiswa tahun berikutnya, mahasiswa baru kuliah ditahun pertama cenderung akan melakukukan konfrontasi atau menghindar konflik yang dihadapi. Hal ini akan berefek pada pola relasi dan tujuan mereka dalam kuliah. Sehingga, selain berfikir kritis, mahasiswa di tahuntahun pertama perlu menerima materi tentang komunikasi dan regulasi diri pada orientasi awal. Penguatan pencapaian soft skil ini juga bisa dilakukan pada pembelajaran di kelas, dengan mengajak mahasiswa mengerjakan tugas-tugas yang bersifat kelompok.

Terlepas dari hasil yang diperoleh, penelitian ini masih membutuhkan bukti pendukung dengan melakukan pengujian multiyears guna menguji hasil bahwa kehidupan di kampus mampu memberikan peningkatan managemen konflik yang lebih konstruktif. Selain itu mengetahui sumber konflik pada mahasiswa juga menjadi hal yang penting berikutnya guna melakukan pembinaan soft skill mahasiswa. 


\section{Kesimpulan}

Hasil penelitian ini menunjukkan bahwa mahasiswa umumnya cenderung lebih memilih cara-cara yang konstruktif dalam menghadapi konflik. Pemilihan manajemen konflik ini lebih karena mahasiswa mempunyai kemampuan untuk melakukan analisa yang baik pada masalah. Semakin berpengalaman menjadi mahasiswa maka individu semakin mampu memilih cara-cara konstruktif dalam mengatasi dan menanggulangi konflik.

Penelitian ini membutuhkan replikasi test-retest, guna menguji hasil penelitian bahwa mahasiswa yang lebih lama duduk dibangku kuliah menjadi lebih kuat. Hasil penelitian ini juga mengungkap kebutuhan mahasiswa untuk mendapatkan pelatihan antisipasi dan resolusi konflik pada masa-masa awal masuk kuliah agar lebih matang saat menjalani perkuliahan di tahun berikutnya.

\section{DAFTAR PUSTAKA}

Aisyah. (2014). Konflik sosial dalam hubungan antar umat beragama, Jurnal Dakwah Tabligh, 15, 2, 189 - 208.

Alfinuha, S., Rohyatin., H.,\& Nuqul., F.L (2017) Individual State when faced a conflict. Proceding of the 6th Asian Psychological Assosiation Convention. 44-53.

Aziz, R \& Mangestuti, R (2006) Pengaruh kecerdasan intelektual, kecerdasan emosional dan kecerdasan spiritual terhadap agresivitas pada mahasiswa UIN Malang. El-Qudwah: Jurnal Penelitian Integrasi Sains dan Islam, 1 (1). pp. 70-84. ISSN 1907-3283

Bahari, H. (2010). Toleransi Beragama Mahasiswa (Studi tentang Pengaruh Kepribadian,Keterlibatan Organisasi, Hasil Belajar Pendidikan Agama, dan Lingkungan Pendidikan terhadap Toleransi Mahasiswa Berbeda Agama pada 7 Perguruan Tinggi Umum Negeri), Laporan Penelitian. Jakarta: Badan Litbang dan Diklat Kementrian Agama.

Baqi, S. A. (2015). Ekspresi emosi marah, Buletin Psikologi, 23, 22 - 30. 
Dhami M, K \& Olsson, H (2008) Evolution of the interpersonal conflict paradigm Judgment and Decision Making, 3. (7). 547-569

Ember, M., \& Ember, C.R. (2000). Testing theory and why the unit of analysis problem is not a problem. Ethnology, 39 (4), 349-363.

Falentina, F. O. \& Yulianti, A. (2012). Asertivitas terhadap pengungkapan emosi marah pada remaja, Jurnal Psikologi, 8, $9-14$.

Forsyith, D. (2010). Group Dynamic. Wadsworth, Cengage Learning

Gayle, N.T \& Nugraheni Y (2012). Komunikasi antar-pribadi: strategi manajemen konflik pacaran jarak jauh. Komunikatif: Jurnal Ilmiah Komunikasi 1 (1) 18-25.

Hanselmann, M \& Tanner, C (2008) Taboos and conflicts in decision making: Sacred values, decision difficulty, and emotions. Judgment and Decision Making, 3, (1), 51-63

Hendrix, S.C. \& Saleyan, I. (2012). Climate change, rainfall, and social conflict in Afrika, Journal of Peace Research, 49, 1, 35 - 50.

Johnson, D.W., \& Johnson. F.P., (1999). Joining Together: Group Theory And Group Skill. London: Printice Hall International Inc.

Kolb, D. M. \& Putnam, L. L. (1992). The Multiple Faces of Conflict in Organizations, Journal of Organizational Behavioral, 3, 3, 311 - 324.

Kompas (2017) Seorang Mahasiswa dikeroyok tawuran pecah di Universitas Pattimura.http://regional.kompas.com/read/2017/10/19/17140481/seoran g-mahasiswa-dikeroyok-tawuran-pecah-di-universitas-pattimura. Diakses 24 Desember 2017

Kurniawan, D. \& Syani, A. (2012). Faktor penyebab, dampak dan strategi penyelesaian konflik antar warga di kecamatan way panji kabupaten lampung selatan, Jurnal Sosiologi, 15, 1, 1 - 12.

Malik, I. (2003). Bakubae: Gerakan Dari Akar Rumput Untuk Penghentian Kekerasan di Maluku. Jakarta: Yayasan TIFA.

Mardianto, A. Koentjoro, \& Purnamaningsih, E.H. (2000). Penggunaan manajemen konflik ditinjau dari status keikutsertaan dalam mengikuti kegiatan pencinta alam di Universitas Gajah Mada. Jurnal Psikologi, 2. 111-119 
Maslow, A.H.(1943). A theory of human motivation. Psychological Review.50 (4): 370-96. doi: 10.1037/h0054346

News Rakyatku (2017) Terungkap ini Penyebab Tawuran antar mahasiswa Unismuh. http://news.rakyatku.com/read/65901/2017/09/18/terungkapini-penyebab-tawuran-antar-mahasiswa-unismuhDiakses 24 Desember 2017

Rachmadani, C, (2013). Strategi komunikasi dalam mengatasi konflik rumah tangga mengenai perbedaan tingkat penghasilan di rt.29 samarinda seberang Ejournal Ilmu Komunikasi, 2013, 1 (1): 212 - 228

Republika (2017) Tawuran Mahasiswa Universitas Riau Coreng Dunia Pendidikan

http://nasional.republika.co.id/berita/nasional/daerah/17/10/06/oxe 7 bs330 -tawuran-mahasiswa-universitas-riau-coreng-dunia-pendidikanDiakses

24 Desember 2017

Robinson, M.D., Wilkowski, B.M, \& Meier, B.P (2008) Approach, avoidance, and self-regulatory conflict: An individual differences perspective. Journal of Experimental Social Psychology 44. 65-79

Priliantini, A. (2008). Hubungan antara gaya manajemen konflik dengan kecenderungan perilaku agresif narapidana usia remaja di lapas anak pria Tanggerang. Jurnal Psiko-Edukasi,6 (1), 10-20

Santrock, J. W. (2012). Life-Span Development; Perkembangan Masa-Hidup Edisi Ketigabelas Jilid 1. Jakarta: Penerbit Erlangga. 